$\underline{\text { Research Article }}$

\title{
Characteristics of Benign Prostatic Hyperplasia (BPH) Patients Undergoing Transurethral Resection of the Prostate (TURP)
}

\author{
Karakteristik Pasien Benign Prostatic Hyperplasia (BPH) dengan Tindakan Transurethral \\ Resection of the Prostate (TURP)
}

\author{
Zen Ary P, Taufiq N Budaya, Besut Daryanto \\ Department of Urology Dr. Saiful Anwar General Hospital Malang
}

\begin{abstract}
Benign prostatic hyperplasia (BPH) is one of the most common diseases affecting the elderly, and Transurethral Resection of the Prostate (TURP) is a gold standard surgical procedure in BPH patients. Although the TURP rate is high, the publication of TURP profile data in Indonesia is still limited. This study aimed at determining the characteristics of BPH patients who underwent TURP at Saiful Anwar General Hospital. This study is a descriptive study by collecting data of 162 BPH patients who underwent TURP from January 2015 to August 2017. TURP is primarily performed in patients aged 61-70 years (39.5\%). Recurrent urinary retention was the most common indication for the procedure (54.9\%) followed by bladder stone (21\%), pharmacological therapy failure (10.5\%), inguinal hernia (8\%), severe Lower Urinary Tract Symptoms (LUTS) (3.7\%), and renal insufficiency (1.9\%). As many as 58\% of patients who underwent TURP had a prostate volume higher than $50 \mathrm{ml}$. Urinary retention is the most common complaint among BPH patients who underwent TURP, and recurrent urinary retention is the most common TURP indicator.
\end{abstract}

Keywords: Benign Prostatic Hyperplasia, recurrent urinary retention, Transurethral Resection of the Prostate

\section{ABSTRAK}

Benign prostatic hyperplasia (BPH) adalah salah satu penyakit paling sering yang menyerang pria lanjut usia, dan Transurethral Resection of the Prostate (TURP) adalah prosedur bedah baku emas pada pasien BPH. Meskipun angka tindakan TURP tinggi namun publikasi data profil TURP di Indonesia masih terbatas. Tujuan penelitian ini adalah untuk mengetahui karakteristik pasien BPH yang menjalani TURP di RSUD Dr. Saiful Anwar. Penelitian ini merupakan penelitian deskriptif dengan mengumpulkan data 162 pasien BPH yang menjalani TURP dari Januari 2015 sampai Agustus 2017. Tindakan TURP paling banyak dilakukan pada pasien usia 61-70 tahun (39.5\%). Retensi urin berulang adalah indikasi paling umum untuk prosedur ini (54.9\%), diikuti oleh batu kandung kemih (21\%), kegagalan terapi farmakologis (10.5\%), hernia inguinalis (8\%), Lower Urinary Tract Symptoms (LUTS) berat (3.7\%), dan insufisiensi ginjal (1.9\%). Sebanyak 58\% pasien yang dilakukan TURP memiliki volume prostat $>50 \mathrm{ml}$. Retensi urin merupakan keluhan tersering yang ditemukan pada pasien BPH dengan retensi urin rekuren merupakan indikasi tersering tindakan TURP.

Kata Kunci: Benign Prostatic Hyperplasia, retensi urin, Transurethral Resection of the Prostate

Correspondence: Zen Ary P. Department of Urology Dr. Saiful Anwar General Hospital, Jl. Jaksa Agung No. 2 Malang Tel. 081326055505 Email:zenaryp@gmail.com

DOI: http://dx.doi.org/10.21776/ub.jkb.2021.031.04.4 


\section{INTRODUCTION}

Benign prostatic hyperplasia (BPH) is a histological diagnosis defined by the abnormal proliferation of smooth muscle and epithelial cells in prostate tissue (1). $\mathrm{BPH}$ is one of the most common diseases affecting the elderly, and its prevalence will increase with age. As of 2010, BPH affect over 210 million men worldwide. BPH is the second most common disease found in urology clinics in Indonesia after urinary tract stones. In 2013 in Indonesia there were 9.2 million cases of $\mathrm{BPH}$, mostly dominated by men aged over 60 years (2). BPH prevalence is on the rise. It is reported that around $70 \%$ of men aged $61-70$ years and $90 \%$ of those aged $81-90$ years have pathological BPH (3-5). Its clinical manifestation as Lower Urinary Tract Symptoms (LUTS) including frequency, urgency, nocturia, intermittency, decreased stream, and hesitancy reduces the patient's quality of life $(6,7)$.

The exact pathophysiology of $\mathrm{BPH}$ is still yet to be identified. It has been linked to many factors including sex hormones, neurotransmitters, inflammation, diet, microorganisms and cellular effects on epithelial as well as stromal tissue that can affect the prostate structure (5). Changes in the prostate structure in BPH include changes in volume and histology (8). Changes in prostate volume vary based on age. Several cross-sectional studies on prostate volume compared with age concluded that prostate volume increases to $25 \mathrm{cc}$ in men aged 30 years and $35-45$ cc in men aged 70 years (9). Its histology change includes hyperplasia of both epithelial and stromal tissues predominantly affects the transition zone of the prostate gland. Hyperplastic nodules then compress the urethra, causing mechanical obstruction to urinary outflow and cause bladder detrusor muscle irritability (10).

The goal of therapy in BPH patients is to improve the patients quality of life. Medical management such as alpha-adrenergic receptors antagonist and 5 alphareductase inhibitors has led to an improvement in symptoms as indicated by a decrease in the incidence of acute urinary retention and indications for surgery (6). Based on the study conducted by Daryanto et al., longterm usage of an alpha-1 blocker for $>6$ months lead to upregulation of alpha-1 receptors, manifested as an increase in mRNA expression of alpha-1 receptors and an increase in prostate smooth muscle contractility (11).

However, under particular circumstances, surgical intervention is needed. Current indications of surgery are based on three main points. The first is treatment failure based on both the IPSS score (increased IPSS score) and from the evaluation of urinary stream (decrease in the maximum flow rate) and increase in residual urine. Second is BPH complication divided into two major groups: complication in the urinary tract (recurrent urinary retention, hematuria, recurrent urinary tract infections, bladder stones, bilateral hydroureteronephrosis, and renal failure) and outside urinary tract (hernia and hemorrhoid). Third is based on the patient's preference of surgical management instead of long-term use of pharmacological treatment $(6,12,13)$.

Transurethral Resection of the Prostate (TURP) is a gold standard procedure for surgery in $\mathrm{BPH}$ patients with a prostate volume of $30-80 \mathrm{ml}$. This procedure is done by circumferentially resecting the prostate tissue from the bladder neck in the superior part of the verumontanum (14). In general, TURP can improve BPH symptoms by up to
$90 \%$ and increase the urine emission rate by $100 \%(15)$. Besides, TURP also reduces the LUTS symptoms and IPSS scores (graded as mild, moderate and severe, based on the severity of LUTS) in $94.7 \%$ of BPH clinical cases and improves the quality of life of patients with BPH (10). The purpose of this study was to determine the characteristics and indications in BPH patients who underwent TURP at Saiful Anwar General Hospital.

\section{METHOD}

This research is a descriptive study using secondary data. The data of subjects studied were obtained from electronic medical records of the Department of Urology, Faculty of Medicine, Universitas Brawijaya/Saiful Anwar General Hospital of 162 BPH patients undergoing TURP from January 2015 to August 2017. The sampling technique was total sampling fulfilled the inclusion criteria. Baseline characteristics of patient including age, prostate volume, chief complaint, and indications of surgery. Inclusion criteria was patients diagnosed with BPH who underwent TURP surgery. The exclusion criteria were patients with incomplete demographic and clinical data records. The result was expressed descriptively in frequency distributions table. Mean \pm standard deviation was shown for numeric variables. The data were analyzed using Statistical Package for Social Sciences SPSS version 28.0 (SPSS Inc., Chicago, Illinois, U.S.A).

\section{RESULTS}

We collected 162 medical record data from BPH patient who underwent TURP at Saiful Anwar General Hospital in January 2015 to August 2017. The subject characteristics consisting of age, prostate volume, chief complaints, indications of surgery, are shown in Table 1.

Table 1. Clinical characteristics of BPH patients undergoing TURP at Saiful Anwar General Hospital

\begin{tabular}{|c|c|c|}
\hline Characteristics & $\mathbf{n}$ & $\%$ \\
\hline Age (years) & 4 & 2.5 \\
\hline $40-50$ years old & 28 & 17.3 \\
\hline $51-60$ years old & 64 & 39.5 \\
\hline $61-70$ years old & 51 & 31.5 \\
\hline $71-80$ years old & 15 & 9.3 \\
\hline $81-90$ years old & 162 & 100 \\
\hline \multicolumn{3}{|l|}{ Prostate Volume (ml) } \\
\hline$<30$ & 24 & 14.8 \\
\hline $31-40$ & 21 & 13 \\
\hline $41-50$ & 23 & 14.2 \\
\hline$>50$ & 94 & 58 \\
\hline Total & 162 & 100 \\
\hline \multicolumn{3}{|l|}{ Chief complain } \\
\hline LUTS & 49 & 30.2 \\
\hline Urinary Retention & 113 & 69.8 \\
\hline Total & 162 & 100 \\
\hline \multicolumn{3}{|l|}{ Indication of Surgery } \\
\hline $\begin{array}{l}\text { Recurrent Urinary } \\
\text { Retention }\end{array}$ & 89 & 54.9 \\
\hline Bladder Stone & 34 & 21 \\
\hline Medical Therapy Failure & 17 & 10.5 \\
\hline Inguinal Hernia & 13 & 8 \\
\hline severe LUTS & 6 & 37 \\
\hline Renal Insufficiency & 3 & 19 \\
\hline Total & 162 & 100 \\
\hline
\end{tabular}


The mean age of patients was $68.1 \pm 9.8$ years (range 43-91 years). The results showed that the age group of BPH patients undergoing TURP mostly was 61-70 years as many as 64 patients (39.5\%), followed by the age group of 71-80 years as many as 51 patients (31.5\%). The results also showed that most BPH patients who underwent TURP had a prostate volume of more than 50 milliliters (58\%) with a mean prostate volume of $57.7 \pm 29.2 \mathrm{ml}$ (range 25-127 ml).

The chief complaints of BPH patients who underwent TURP were urinary retention and LUTS as many as 113 patients (69.8\%) and 49 patients $(30.2 \%)$, respectively. Table 1 also shows that most BPH patients who underwent TURP experienced recurrent urinary retention, as many as 89 patients $(54.9 \%)$. The most common indications were urinary tract stones $(21 \%)$ followed by medical therapy failure $(10.5 \%)$, hernia or hemorrhoids (8\%).

\section{DISCUSSION}

The results of this study show that TURP is primarily performed among patients aged $61-70$ years (39.5\%), with repeated urinary retention as the most prominent indication (54.9\%), and most patients (58\%) have prostate volume higher than $50 \mathrm{ml}$. As many as $15 \%$ to $60 \%$ of men aged over 40 years experienced $\mathrm{BPH}$. Generally, the prevalence of $\mathrm{BPH}$ will increase with age (10). In an autopsy study, as many as $8 \%$ of men aged 40 years experienced $\mathrm{BPH}$. This figure rose to $50 \%$ and $80 \%$ among men aged 60 and 90, respectively (3). However, our study showed that TURP was more commonly performed in men of 61-70 age groups with a mean age of 68.1 years. Agrawal et al., showed similar results, the mean age for patient underwent TURP was $62.1 \pm 8.22$ years in 2006 and $66.94 \pm 9.12$ years in 2016 . Why the older age group rarely underwent TURP needs to be explored. It is possible that the usage of pharmacotherapy, due to its established role in combating LUTS, decreasing prostate size, and steadying disease progression, became the first-line treatment in the management of $\mathrm{BPH}$, hence the constant decline in the number of TURPs being performed in this age group (16).

In our study, most patients had a prostate volume of more than 50 milliliters (58\%) with a mean prostate volume of $57.7 \pm 29.2 \mathrm{ml}$ with a maximum volume of $127 \mathrm{ml}$. The EAU guidelines, based on grade $A$ evidence, recommends TURP for prostates between 35 and $80 \mathrm{ml}$. Over that limit, open surgery seems to remain the only option for treating $\mathrm{BPH}$, according to available clinical evidence. Still, in many cases, for the experienced urologist, TURP may represent a better alternative. A study by Persu et al., showed that TURP is equally effective for both mid-sized and large prostates compared to open prostatectomy with the main disadvantages of a slightly higher rate of urinary incontinence and urethral strictures (17).

The most common chief complaint in our patient was LUTS. Lower Urinary Tract Symptoms (LUTS) consists of storage and voiding symptoms. Storage symptoms experienced during the storage phase of bladder filling

\section{REFERENCES}

1. Wei JT, Calhoun E, and Jacobsen SJ. Urologic Diseases in America Project: Benign Prostatic Hyperplasia. The Journal of Urology. 2005; 173(4): include daytime frequency and urgency as well as nocturia. Detrusor overactivity (DOA) is thought to be a contributor to storage symptoms. Voiding symptoms experienced during the voiding phase may include straining to urinate, intermittent urinary stream, and weak urinary stream. BPH has been proposed to contribute to overall LUTS via at least two routes: direct bladder outlet obstruction (BOO) from enlarged prostatic tissue and increased smooth muscle tone and resistance within an enlarged prostate gland (14). Monopolar TURP (M-TURP) has dominated surgical treatment of LUTS due to BPH (LUTS-BPH) for $>70$ years. A retrospective single institution experience review reported that although combined medical therapy use had increased from $5 \%$ to $58 \%$, failed 'medical therapy' as an indication for TURP also increased from $36 \%$ in 1998 to $87 \%$ in 2008 (18).

Twenty five percents of chronic urinary retention patients will be managed by TURP. The CLasP study showed that TURP was found significantly effective to relieve LUTS, improve Qmax and health-related quality of life (HRQL), decrease PVR (post-void residual), and showed comparable outcome to low power laser coagulation therapy (19). Also, several complications of BPH that are strong indications of TURP are [1] recurrent urinary retention, [2] recurrent hematuria after being swept with 5a-reductase inhibitors, [3] renal insufficiency or superior urinary tract dilatation, [4] bladder stones in the urinary tract, [5] recurrent urinary tract infections (13). This is consistent with the results of the study that the TURP indications are recurrent urinary retention (54.9\%), urinary tract stones (21\%), failure of medical therapy (10.5\%), hernia or hemorrhoids (8\%), severe LUTS (3.7\%), and renal insufficiency (1.9\%).

This study also found an inguinal hernia as an indication of TURP. The need to push while urinating among the elderly with a weak abdominal wall will lead to a hernia. Besides, patients with hernia often have LUTS symptoms (7). Transurethral Resection of the Prostate (TURP) that is performed simultaneously with hernioplasty do not show any major complications and prolonged hospital stay (20). By performing TURP, the incidence of hernia can decrease.

The limitation in this study are the retrospective design is subject to numerous biases, and the data were obtained from registries prone to misclassification bias. Future studies may be necessary to perform in a larger population with a larger sample size to represent the general population.

In conclusion, our study showed that TURP has stood the test of time in the surgical management of $\mathrm{BPH}$ and remained to be the surgical choice in $\mathrm{BPH}$ patients with LUTS symptoms, chronic urinary retention, and prostate volume larger than $50 \mathrm{ml}$.

\section{ACKNOWLEDGEMENT}

This study was supported by Urology Residency Program Faculty of Medicine Universitas Brawijaya and Saiful Anwar General Hospital Malang.

2. Adelia F, Monoarfa A, and Wagiu A. Gambaran Benigna Prostat Hiperplasia di RSUP Prof. Dr. R. D. Kandou Manado Periode Januari 2014 - Juli 2017. 
Jurnal e-Clinic. 2017; 5(2): 250-252.

3. Lim KB. Epidemiology of Clinical Benign Prostatic Hyperplasia. Asian Journal of Urology. 2017; 4(3): 148-151.

4. Bray F, Ferlay J, Soerjomataram I, Siegel RL, Torre LA, and Jemal A. Global Cancer Statistics 2018: GLOBOCAN Estimates of Incidence And Mortality Worldwide For 36 Cancers In 185 Countries. CA: A Cancer Journal for Clinicians. 2018; 68(6): 394-424.

5. Lokeshwar SD, Harper BT, Webb E, et al. Epidemiology and Treatment Modalities for the Management of Benign Prostatic Hyperplasia. Translational Andrology and Urology. 2019; 8(5): 529-539.

6. Rosette JJD, Alivizatos G, Madersbacher S, et al. Guidelines on Benign Prostatic Hyperplasia (BPH). European Urology. 2001; 40(3): 256-263.

7. Kapoor A. Benign Prostatic Hyperplasia (BPH) Management in the Primary Care Setting. The Canadian Journal of Urology. 2012; 19(1): 10-17.

8. Tjahjodjati. Panduan Penatalaksanaan Klinis Pembesaran Prostat Jinak (Benign Prostatic Hyperplasia/BPH). Edisi 3. Jakarta: Ikatan Ahli Urologi Indonesia; 2017.

9. Hiort O, Birnbaum W, Marshall L, et al. Management of Disorders of Sex Development. Nature Reviews. Endocrinology. 2014; 10(9): 520-529.

10. Kim EH, Larson JA, and Andriole GL. Management of Benign Prostatic Hyperplasia. Annual Review of Medicine. 2016; 67: 137-151.

11. Daryanto B, Ali M, Purnomo BB, and Mintaroem K. Upregulation of Alpha-1 Receptor Gene Expression in Benign Prostate Hyperplasia Patients Receiving Long-Term Alpha-Blocker Therapy. Drug Inventory Today. 2019; 12(4): 657-662.

12. Budaya TN and Daryanto B. A to $Z$ BPH (Benign Prostatic Hyperplasia). Malang, Jawa Timur: UB Press; 2019; p. 138.
13. Ingimarsson JP, Isaksson HJ, Sigbjarnarson HP, Gudmundsson J, and Geirsson G. Increased Population Use of Medications for Male Lower Urinary Tract Symptoms/Benign Prostatic Hyperplasia Correlates with Changes in Indications for Transurethral Resection of the Prostate. Scandinavian Journal of Urology. 2014; 48(1): 73-78.

14. Macey MR and Raynor MC. Medical and Surgical Treatment Modalities for Lower Urinary Tract Symptoms in the Male Patient Secondary to Benign Prostatic Hyperplasia: A Review. Seminars in Interventional Radiology. 2016; 33(3): 217-223.

15. Rajeev R, Giri B, Choudhary LP, and Kumar R. Surgery for Benign Prostatic Hyperplasia: Profile of Patients in a Tertiary Care Institution. The National Medical Journal of India. 2017; 30(1): 7-10.

16. Agrawal $M$, Kumar M, Pandey S, Aggarwal A, and Sankhwar S. Changing Profiles of Patients Undergoing Transurethral Resection of the Prostate Over a Decade: A Single-Center Experience. Urology Annals. 2019; 11(3): 270-275.

17. Persu C, Georgescu D, Arabagiu I, Cauni V, Moldoveanu C, and Geavlete P. TURP for BPH. How Large is Too Large? Journal of Medicine and Life. 2010; 3(4): 376-380.

18. Mayer EK, Kroeze SGC, Chopra S, Bottle A, and Patel A. Examining the "Gold Standard": A Comparative Critical Analysis of Three Consecutive Decades of Monopolar Transurethral Resection of the Prostate (TURP) Outcomes. BJU International. 2012; 110(11): 1595-1601.

19. Negro CLA and Muir GH. Chronic Urinary Retention in Men: How We Define It, and How Does it Affect Treatment Outcome. BJU International. 2012; 110(11): 1590-1594.

20. Fan YH, Chung HJ, Huang E, Lin A, and Chen KK. Mp310 Reduction of Enlarged Prostate Decreases the Incidence of Inguinal Hernia. The Journal of Urology. 2015; 193(4S): e22. 